\title{
The Economic Impact of COVID-19 on Construction Industry: Oman's Case
}

\author{
Tariq Al Amri
}

\section{ABSTRACT}

With the sudden onset of the COVID-19 pandemic in 2020, global economies have been severely disrupted. The decline of the aviation industry and the fall in global demand for goods and services have proved to be fatal for many countries already struggling with economic issues before the pandemic. In particular, for the Omani economy, falling oil prices and supply chain disruptions have dealt a severe blow to the construction industry. Not only the construction industry has seen a fall in financial support and funding, many players in the industry have also sustained the hit that further increases the financial burden of Oman's construction industry. In this article, the economic impacts of the COVID-19 pandemic on Oman's construction industry are analyzed using an inductive reasoning approach. Data are gathered from primary and secondary sources. Although the pandemic consequences are cruel, it is an opportunity to improve paradigms to absorb such events in the future.

Keywords: COVID-19, economic impact, construction industry, Oman.
Submitted : March 08, 2021

Published : April 08, 2021

ISSN: 2507-1076

DOI: $10.24018 /$ ejbmr.2021.6.2.806

Tariq Al Amri*

Dhofar Academia, Oman

(e-mail: admin@dhofaracademia.com)

*Corresponding Author

\section{INTRODUCTION}

Over the last ten years, the Middle East has seen massive progress within its construction sector as a result of the thriving oil production sector. In fact, Oman is known as one of the 'oil-producing countries' within the Middle East, where the oil sector has had significant contribution to its economic growth since it accounts for 30\% of Oman's total gross domestic product (GDP). (International Trade Administration, 2020). Apart from oil production, the second largest contributing factor to Oman's economic growth can be attributed to the construction industry. When analyzing countries with significant growths in the building and construction industry, Oman has been featured as one of the top countries since 2015 [30]. According to government statistics, a $9.4 \%$ annual growth rate was recorded for the Omani construction industry from 2012 to 2016. A huge contributor to this unprecedented growth rate in the Omani construction industry was a result of the Eighth Five-Year Developmental Plan implemented by the Omani government between 2010 to 2015 [3].

Even after the end of the Eighth Five-Year Developmental Plan, the Omani construction industry is forecasted to generate a compound annual growth rate (CAGR) of $6 \%$ between 2019 to 2024. This growth rate is further increased as a result of Oman's Vision 2020 program and its Ninth FiveYear Development Plan which aims to diversify the Omani economy and reduce reliance on oil sectors. In order to achieve these goals, the Omani government planned to increase the GDP contribution of the heavy industry to $29 \%$ by the end of 2020. Therefore, a total of USD 106 billion has been invested by the government into the non-oil industries, which includes the construction industry. As can be seen in Table 1, there have already been 1840 active projects in the urban construction industry in 2018, as compared to 230 projects in the utilities industry, 150 projects in the transport industry, and 110 projects in the industrial industry. In addition, active projects in the urban construction far surpass those in the oil and gas industry which only has 70 projects in total [24]. This proves how the Omani government have begun to prioritize investments in the construction industry over other industries.

TABLE I: TOTAL NO. OF ACTIVE PROJECTS IN VARIOUS SECTORS IN 2018

\begin{tabular}{cc}
\hline Sectors & $\begin{array}{c}\text { Total No. of Active } \\
\text { Projects in 2018 }\end{array}$ \\
\hline Urban Construction & 1840 \\
Utilities & 230 \\
Transport & 150 \\
Industrial & 110 \\
\hline
\end{tabular}

Henceforth, it is clear that the construction industry has been booming in Oman and is forecasted to continue its unprecedented growth. However, the sudden onset of the COVID-19 pandemic threw the world into a frenzy, with countries scrambling to contain the virus by imposing lockdowns. These unprecedented measures critically impacted businesses and the economic growth of countries globally. Consequently, the construction industry is reeling from the devasting impacts of the pandemic [35]. Among these impacts, concerns about the workforce have been one of the key issues. These concerns lie in how the construction industry is heavily dependent on laborers from low-income countries. Unfortunately, overseas laborers are now bound by strict travel restrictions which prevent the inflow of the workforce, resulting in a massive shortage in the labor supply 
for the construction industry [1].

The decrease in the number of expatriate workers in the construction industry is evident from how in 2019, there were a total of 490,206 workers. However, by the end of 2020 where the effects of the pandemic were felt around the world, there were only 379,493 expatriate workers in the construction industry, which is a $22.6 \%$ decrease from the previous year [23]. This is a much greater decrease in expatriate construction workers as compared to Omani construction workers, which fell 7\% from 58,793 in December 2019 to 54,635 in December 2020 [23].

TABLE II: TOTAL NUMBER OF EXPATRIATE WORKERS IN OMAN FROM

\begin{tabular}{cc} 
& 2017 TO 2021 \\
\hline Year & $\begin{array}{c}\text { Total Number of Expatriate } \\
\text { Workers in Construction Industry }\end{array}$ \\
\hline Jan 2019 & 490,206 \\
Q1 2020 & 561,981 \\
Q2 2020 & 454,027 \\
Q3 2020 & 419,610 \\
Q4 2020 & 378,539 \\
Jan 2021 & 490,206 \\
\hline
\end{tabular}

(Source: NCSI).

Based on Table II above, it is evident that throughout 2020, the number of expatriate workers in Oman's construction workers has been steadily decreasing. By Q4 of 2020, there has already been a 32.7\% decrease in workers from Q1 2020. This emphasizes the serious issue of how the pandemic has affected the labor supply available in Oman. However, despite this overall decrease in expatriate construction workers throughout 2020, the increase observed in Jan 2021 to 490,206 expatriate construction workers demonstrates a positive outlook for the industry in the long term as recovery takes place.

Apart from such issues faced, economic impacts resulting from the pandemic have also drastically affected Oman's construction industry. The large drop in prices of oil, decreased performance of the private sector, and supply chain cuts have begun to pose many issues for the construction industry. Therefore, this summary report aims to analyze and discuss these economic impacts of COVID-19 on Oman's construction industry.

\section{Methodology}

Since the COVID-19 pandemic has only recently occurred in 2020, there is a general lack of research analyzing the economic impact of COVID-19 on the construction industry in Oman specifically. While such reports do exist, they are minimal and present many research gaps to be tackled. Given the importance of the construction industry in being the second highest contributor to Oman's GDP, it is essential to address these research gaps to identify the pandemic's economic impacts. Thus, this will help parties mitigate any further damage to Oman's construction industry and economic growth.

Before delving into how economic growth will be analyzed in this report, it is essential first to establish the definition of economic growth, which this report will follow. According to pioneer economist Weisbrod, 'economic impacts are effects on the level of economic activity in a given area' [34]. Economic impacts can be categorized into three categories, namely direct, indirect, and induced economic effects. Direct economic effects measure the immediate impact of the event on the industry's economic output being measured, in this case, Oman's construction industry. On the other hand, indirect and induced economic effects are often measured together. Indirect economic effects measure how numerous cycles of expenditure by other economic participants impact the economic activity of the industry being measured [34]. At the same time, economic activity can be measured through analyzing the four factors of resource management, production of goods and services, distribution of goods and services, as well as the consumption of these goods and services [9]. Therefore, based on this definition, the report will analyze the economic impact of COVID-19 on Oman's construction industry through measuring both the direct and indirect economic impacts on the industry.

In doing so, a combination of primary and secondary resources will be used throughout the research. While there is an existent of secondary sources measuring the impact of COVID-19 on Oman's construction industry, these sources are few. Most secondary sources also take on a broader perspective in analysing all forms of impact on the industry. Unfortunately, despite being a key factor in influencing the country's economic growth, economic impacts were not analyzed in detail compared to social and political impacts. Therefore, this report aims to fill the gaps that exists within current secondary resources to identify the economic impacts in detail, so that specific measures can be taken to tackle the issues. In order to fill these gaps, primary sources and data will be drawn upon to conduct these analyses. Primary sources that will be used include official government statistics on relevant economic figures, annual economic reports released by Oman, as well as newspaper articles.

Primary sources will be analyzed in tandem with existing scholarship through the inductive method of analysis in order to derive the economic impacts of COVID-19 on Oman's construction industry. In doing so, specific observations will be conducted to identify the patterns that shed light on the economic impacts in question. The use of inductive analysis is relevant for this paper due to the significantly larger amounts of raw data available to analyze economic impacts, as compared to secondary data. Therefore, according to Strauss and Corbin, inductive analysis would '[allow] the theory to emerge from the data' [31]. Furthermore, inductive analysis would allow the economic impacts to be analyzed based on the dominant patterns observed from data collected, making the analysis much more accurate and representative of all data analyzed [32].

\section{ECONOMIC IMPACT OF COVID-19}

\section{A. COVID-19}

According to the World Health Organization, COVID-19 is 'an infectious disease caused by a newly discovered coronavirus' [4]. The outbreak was first identified in Wuhan, China in December 2019. Slowly but steadily, the virus began to make its way globally. Within just a month, the DirectorGeneral of the World Health Organization, António Guterres, declared the COVID-19 outbreak as a public health emergency on 30 January 2020 [4]. He called for all countries 
to do everything possible to halt the spread of the virus and rolled out a set of guidelines to follow. To date, the United States and European countries have been one of the hardest hit countries by the pandemic. Furthermore, many countries, such as South Korea, has also reported multiple waves of the coronavirus. As of 27 January 2021, there have been 43,985,015 confirmed cases in the Americas and 33,262,705 cases in the Europe, among many millions of cases worldwide [4].

\section{B. Economic Impact of COVID-19on Oman}

As a country that is heavily dependent on oil exports, the effects of the global pandemic on causing oil prices to plummet rapidly has resulted in serious repercussions on the Omani economy [29]. Rapidly plummeting oil prices can be seen from Fig. 1. It is evident that in Dec 2019, before the effects of the pandemic were experienced worldwide, the price of oil in Oman was valued at $60.26 \mathrm{US} \$ / \mathrm{bbl}$. However, by June 2020, the value of oil has already dropped to 23.65 US $\$ / b b l$, which was the lowest value experienced since April 2003.

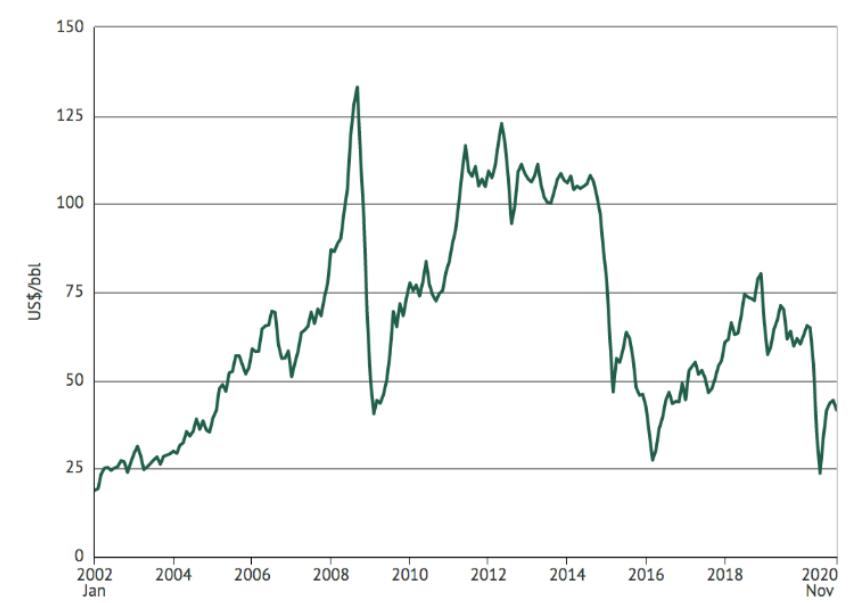

Fig. 1. Average Price of Crude Oil in Oman from 2002 to 2020 [22].

Furthermore, Oman has a relatively larger population as compared to the rest of the Gulf countries, making the economic situation worse for the government due to the smaller rent-per-capita that the population is responsible for. To make the strain on Oman's economy worse, its government bonds were relegated by three rating agencies based on the plummeting prices of oil and increased demands for government spending. According to Dr Hatem Al Shanfari, an Omani analyst, this relegation of government bonds intensified the negative impacts on the Omani economy. Overall, the effects of the pandemic have resulted in Oman's estimated public debt increasing to $77.1 \%$ of Oman's GDP [29].

In response to these economic impacts on Oman, the government has come up with a set of financial measures to combat the impacts. One of these measures include the formation of a committee that will focus their efforts on studying the economic repercussions of the pandemic on Oman. The government has also focused its efforts on increasing consumption in the economy by stimulating demand, upholding financial stability, and ensuring that affected industries are able to stay afloat. These would be achieved through a couple of measures aimed at stimulating liquidity, reducing the cost of borrowing, and ensuring that businesses are able to gain continued access to credit. The repayment of private sector loans was also encouraged to be postponed by six months by the Central Bank to aid the recovery of affected businesses [12].

However, while economic impacts on the Omani economy in general has been affected by a drop in oil prices and a decrease in demand and consumption, how has these impacts trickled down to the construction industry? The following sections will explore how the economic impacts of the COVID-19 pandemic as highlighted in this section has affected the Omani construction industry.

\section{ECONOMIC IMPACTS OF COVID-19 ON OMAN'S CONSTRUCTION INDUSTRY}

This chapter will examine in detail the economic impacts of COVID-19 on Oman's construction industry by delving into both direct and indirect economic impacts. Before delving into the impact on the construction industry, in particular, it is important to emphasize some of the economic impacts sustained by the Oman's economy in general. Firstly, the government has experienced a surge in demand for financial resources as a result of the large decrease in demand. This is clear from how by the end of June 2020, total public expenditure in Oman fell by $8.4 \%$ to RO5.65 billion [28]. Furthermore, the drop in demand and consumption in the economy also has indirect impacts on affecting the costs incurred by the construction projects, funding that the industry has access to, as well as investments in the construction industry. The following sections will delve deeper into analyzing how these economic impacts affected Oman's construction industry.

\section{A. Economic Impact of Plummeting Oil Prices}

1) Short Term/Direct Impact: Decreased Funding and Financial Support from the Omani Government

Similar to the situation faced in 2007 by Oman, a decrease in the oil production of the country resulted in public expenditure cuts by the government which immediately trickled down to the construction industry. As a result of the plummeting oil prices, the Omani economy has contracted sharply by at least 9\% [27]. Therefore, subsequent public expenditure cuts also meant decreased funding and financial support from the Omani government for construction projects.

Oil prices heavily impact Oman's economy and subsequently, the construction industry as Oman is part of the oil exporting nations. The strong impact of oil prices on the economy is evident from how oil is responsible for $75 \%$ of the Omani government revenue [11]. Since oil prices are reliant on supply and demand, the impact of COVID-19 has led to a dramatic decrease in demand, resulting in the large fall in oil prices globally [8] The fall in oil prices as a result of the pandemic has had a strong impact on Oman's economy as demonstrated in Figures 2 and 3. From Figures 2 and 3, it is clear that the rise and fall of Oman's GDP mirrors the trend reflected by the GDP gained from petroleum activities. 


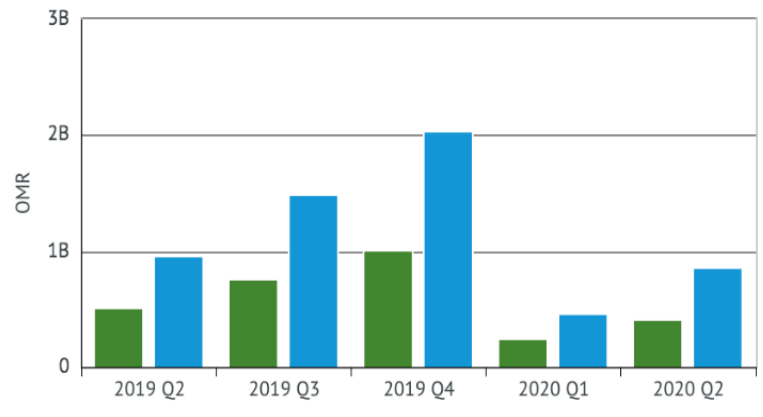

Petroleum Activities $\square$ Non - Petroleum Activities

Fig. 2. GDP of Petroleum and Non-Petroleum Activities in Oman from 2019 to 2020 [23]

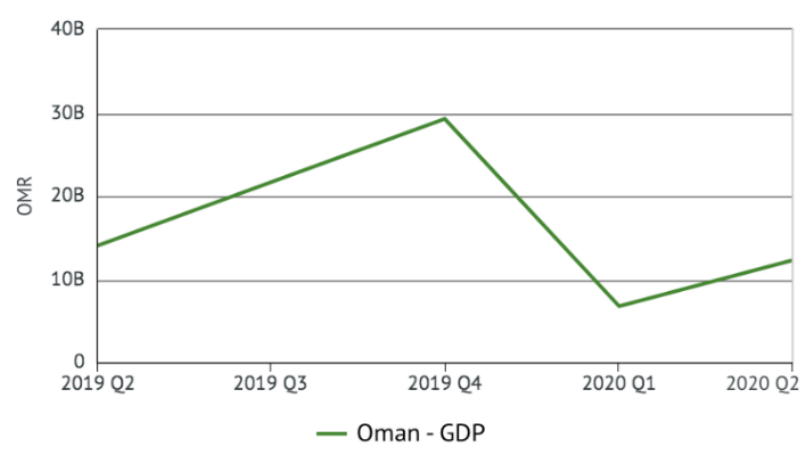

Fig. 3. GDP of Oman from 2019 to 2020 [23].

As a result of the fall in oil prices and the subsequent contraction of the Omani economy, the Omani government is put in a weak fiscal position where it now has to channel spending towards more important sectors. This rationalization in government spending has led to several cuts in government spending in the public sector, which will continue to be the main focus from 2021 onwards. The Omani government's economic plans for 2021 is highlighted in the Medium-Term Fiscal Plan (MTFP) conceptualized by Oman's Ministry of Finance. The MTFP demonstrated the country's intentions to increase state reserves, reduce public debt, and diversify the economy away from its heavy reliance on oil [15]. While the MTFP spells short term economic disadvantages, it can also spell long-term advantages for Oman's construction industry.

As mentioned above, short term economic disadvantages of this shift in focus for government spending away from public projects would result in a reduction of funding for Oman's construction industry. This is so as construction projects which are characterized as public projects, have traditionally relied heavily on the government [27]. Furthermore, economist Yasmine Ghozzi, evaluated that Oman's construction industry would experience a very slow recovery due to the low likelihood of the government in increasing investments in construction projects in the short term. As a result of the decreased government spending in the construction industry, the output of the industry is expected to further contract by $5.8 \%$ in 2021 [33].

2) Long Term/Indirect Impact: Strain on Construction Industry Key Players

Apart from the negative short-term economic impacts, negative long-term impacts will also be faced by the construction industry as a result of the economic downturn. Firstly, there will be a decrease in demand for residential and commercial projects as a result of increased unemployment rates and low GDP growth. While there will be companies which will still be able to execute their construction projects, it is predicted that these companies will be few.

In fact, construction companies that already have high levels of debt incurred as well as low cash reserves would begin to face liquidity issues. Other parties involved in construction projects, such as sub-contractors, will begin to face serious issues since smaller companies may have trouble coping with the economic impacts. As a result of the difficulties faced by involved parties, contracts will start to become strained as customers look to renegotiate or terminate the contracts. Construction companies might also start to see that their long-term prospects for internationalization are diminished due to increased global restrictions and the economic downturn [6].

3) Long Term/Indirect Impact: Increased Investments to Develop Infrastructure

However, some long-term positive impacts might also exist for Oman's construction industry as a result of the COVID-19 pandemic. The crippling of the Omani economy by oil prices has led to increased efforts by the government to diversify its economy away from the reliance on oil. A part of these measures includes more investments in development projects in the long run. According to the MTFP, the Omani government aims to diversify its national revenue through various measures. This would include the investment of OR371 $\mathrm{m}$ into various development projects in Oman by 2024 [15]. In Oman's 2020 budget, USD 13.77 billion has already been allocated by the government to spur development projects. Within this amount, USD 7.01 billion has been set aside for industrial and service construction projects, USD 3.38 billion for infrastructure construction projects, and oil and gas construction projects each.

In addition, the Omani government has also conceptualized plans to develop new national rail networks, such as one that will connect Muscat and the United Arab Emirates. Furthermore, plans to develop a new port city at Sohar Port has already been ongoing, with huge investments made into the project. Apart from the development of such infrastructure, the demand for private real estate is expected to increase in the future. Therefore, plans to build more shopping malls, office spaces, and tourism complexes are also ongoing to prepare the country once global travel is enabled.

It is clear that, the economic impact of COVID-19 has further pressed the government to diversify its economy from the oil sectors, resulting in more investments in the construction industry in the long run. In fact, the construction industry is expected to grow further, in addition to its current projects amounting to USD 327.63 billion [24].

\section{B. Economic Impact of Slowed Performance in the Private Sector}

Furthermore, given the economic slowdown, the private sector has also seen a decrease in activity which would result in less financial investments for the constructor industry. The impact on the private sector poses an issue for Oman's construction industry as the industry has started to rely on the private sector to fill funding gaps in recent years. 
In fact, the private sector has had strong involvement in the construction industry since the Omani government started to develop construction projects under public-private partnerships (PPP). Construction projects conducted under the PPP model is where a private or multinational company and a state-linked institution works together to carry out the project. In fact, the PPP model has become very substantial in the construction industry over the past decade. By the end of 2017, there were already 11 PPP construction projects worth \$2bn in its planning stages [26]. In addition, the Omani government also set up the \$1bn Rakiza Fund in 2018 in order to attract investments in various sectors. While the PPP model has been around since the mid 1990s, its success was mainly found in the building of water and power generation plants. Therefore, in 2019, the Omani government further steppedup efforts to encourage the use of PPP models in new construction projects. For example, in July 2019, the government created a strong framework to support publicprivate infrastructure. The benefits of the PPP model for the Omani construction industry were mainly found in being able to reduce costs incurred by the government in supporting construction projects, and in also being able to sustain economic growth in the country. The Omani government is expected to further spur the country's construction projects through the PPP model in the upcoming years, through attracting more private investments [11].

Given that private investments are crucial in spurring the growth of Omani's construction industry, the resulting economic slowdown from COVID-19 is bound to affect the financing of Omani's construction projects. With the current economic crisis, many enterprises have found that they are facing numerous issues in achieving their financial obligations, resulting in a 'domino effect' which leads to a fall in global investment flows (PricewaterhouseCoopers, 2020). For example, reports from the OECD have speculated a fall in foreign direct investment flows by $30 \%$ by the end of 2020 [8]. In Oman, foreign direct investments fell from 573.200 Omani Rial in the 4th quarter of 2019, to just 476.700 Omani Rial in the 1 st quarter of 2020 . These figures can be seen in Table III.

TABLE III: TOTAL FOREIGN DIRECT INVESTMENTS RECEIVED BY OMAN FROM 2019 TO 2020 [22]

\begin{tabular}{cccccc}
\multicolumn{7}{c}{ FROM 2019 TO 2020 [22] } \\
\hline Time & 2019 Q1 & 2019 Q2 & 2019 Q3 & 2019 Q4 & 2020 Q1 \\
\hline $\begin{array}{c}\text { Total } \\
\text { FDI (OR) }\end{array}$ & $1,518.900$ & -570.900 & 372.000 & 573.200 & 476.700 \\
\hline
\end{tabular}

Furthermore, Kousthuba Raja, the executive of Omanbased engineering and construction company Abu Hatim Group, has discussed the effects of how the current economic recession has led to late government payments to construction contractors. [11] What this spell for the construction industry is significant delays in the construction projects which will incur higher costs for the parties involved. The effects of higher costs incurred by Omani's construction industry will be further discussed in the following section.

\section{Economic Impact of Construction Project Delays}

\section{1) Force Majeure}

As a result of COVID-19, contractual obligations and the availability of resources have become an obstacle, causing project delays and cancellations that have resulted in significant costs incurred by the construction industry. FMI Research has recently conducted a study that reflected that the Omani construction sector will see significant delays in its construction projects as a result of schedule conflicts caused by the pandemic.

More specifically, the clause of 'Force majeure' might be used by parties involved in construction projects to repeal their contractual obligations. 'Force majeure' is a contractual clause that frees parties from liability due to the occurrence of unforeseen circumstances. In Oman's Civil Transactions Law, Article 172 states that 'in bilateral contracts, if force majeure occurs rendering the performance of the obligation impossible to complete, the corresponding obligation shall be extinguished, and the contract shall automatically be revoked'. While COVID-19 might not have been announced as a force majeure event, this clause could still be invoked by parties involved in construction projects. In the event of such conflicts, construction project owners will need to evaluate the clauses in the contract to determine how the pandemic might affect the completion of the project. If the clause is invoked or the project is delayed due to various issues, a significant loss of profits and higher costs would be incurred by the owner of the project [13].

\section{2) Supply Chain Cuts}

Furthermore, Oman's construction industry is heavily reliant on supplies obtained from other regions, causing the industry to be impacted by the economic conditions of these regions as well. Firstly, Oman is expected to see rising construction costs as a result of the increase in prices of building materials overseas. In fact, the increase in construction costs is expected to be around $20 \%$. Given that Oman's construction industry obtains its supplies from regions such as China, Europe, India, and Turkey, the breakdown of the global supply chain has led to these regions increasing the cost of their goods [2]. Basic construction materials such as copper, aluminum, and casework have already seen price increases [6]. Also, prices of containers have increased by 3 times, where a $40 \mathrm{ft}$ container that usually costs $\$ 1000$ now costs between $\$ 3000$ to $\$ 4000$ [2].

Apart from the rising costs of construction materials, the disruption of the aviation industry has also resulted in a shortage of supplies. As a result of the pandemic, freight landing costs incurred by supplies companies have increased dramatically. For example, in Oct 2020, an increase of \$2 per $\mathrm{kg}$ for airline freight rates have been incurred in just two weeks. In fact, this rate was expected to increase to $\$ 7$ per $\mathrm{kg}$ [14].

Therefore, it is clear that the pandemic has had a considerable impact on causing construction project delays as a result of global supply chain cuts and the possible invocation of force majeure. In such instances, the owner of the project is expected to incur higher costs in building materials, as well as to support the prolonged project.

\section{CONCLUSION}

COVID-19 has had devastating impacts on the Omani economy due to the severe drop in oil prices and supply chain cuts. The fall in oil prices has led to Omani's economic growth taking a hit, resulting in the government's need to 
divert its spending to more pressing sectors. Therefore, the construction industry has seen a cut in government funding in the short term. Furthermore, rising costs in building materials globally further add on to the financial strain that construction companies face. What compounds the rising costs in building materials is the increase in freight costs due to the pandemic's disruption of the aviation industry. As a result of such rising costs and the pandemic's unprecedented occurrence, the likelihood of force majeure being invoked by companies involved in construction contracts is higher.

Additionally, the increasing reliance of the construction sector on private investments through PPP projects is likely to cause additional financial strain for construction companies. The strain in Omani's economic growth would affect private companies' performance, thus resulting in a decreased ability in companies being able to invest in these projects. As a result, private investments have already seen a drop due to the pandemic. It is evident that the Omani construction sector has experienced negative economic impacts built on various levels in the short term. However, in the long run, the construction sector is expected to see more significant investments by the government due to its endeavor to diversify the economy from oil production.

\section{RECOMMENDATIONS}

In the short run, experts have recommended that Omani construction companies should focus on restructuring their strategies to tide through the pandemic. Furthermore, companies can also cushion the economic impacts by preparing for possible negotiation of contracts and increased costs. In dealing with supply chain disruptions, construction companies should reach out to their suppliers to create a dashboard that can be improved over time. Such a dashboard would help struggling companies more explicitly identify the financial implications of supply chain disruptions and the best measures to deal with each problem. Construction companies must ensure that any supply chain changes can be supported by their companies' project and risk management controls [5]. Therefore, while the COVID-19 pandemic might have considerable negative economic impacts on the Omani construction industry, this does not spell disaster for construction companies. It can be an opportunity to rethink and improve their business models.

\section{REFERENCES}

[1] Al Amri, T., \& Marey-Pérez, M. (2020). Impact of Covid-19 on Oman's Construction Industry. Technium Social Sciences Journal, 9, 661-670. doi: $10.47577 /$ tssj.v9i1.1021.

[2] Building material prices to go up in Middle East by 20\%. (2021). Retrieved 1 February 2021, from https://timesofoman.com/article/building-material-prices-to-go-up-inmiddle-east-by-20.

[3] Construction in Oman - Key Trends and Opportunities to 2022. (2021). Retrieved 1 February 2021, from https://store.globaldata.com/report/gd-cn0393mr--construction-inoman-key-trends-and-opportunities-to-2022/.

[4] Coronavirus. (2021). Retrieved 1 February 2021, from https://www.who.int/health-topics/coronavirus\#tab=tab_1.

[5] COVID-19: What it means for engineering and construction: PwC. (2020). Retrieved 1 February 2021, from https://www.pwc.com/us/en/library/covid-19/coronavirus-impactsengineeringconstruction. Html.
[6] Deloitte. Understanding the sector impact of COVID-19: Engineering \& Construction.

[7] Engineering \& Construction in a post-COVID world: weathering the storm. (2020). Retrieved 8 February 2021, from https://www.pwc.com/gx/en/issues/crisis-solutions/covid19/engineering-construction-post-covid-world.html.

[8] Foreign direct investment flows in the time of COVID-19. (2021). Retrieved 1 February 2021, from https://www.oecd.org/coronavirus/policy-responses/foreign-directinvestment-flows-in-the-time-of-covid-19-a2fa20c4/.

[9] Goodwin, N., Harris, J., Nelson, J., Roach, B., \& Torras, M. (2013). Microeconomics In Context (4th ed.). Routledge.

[10] Gross Domestic Product - DATA PORTAL. (2021). Retrieved 1 February 2021, from https://data.gov.om/tiwdkoe/gross-domesticproduct.

[11] How will Covid-19 affect Gulf diversification efforts? (2021). $\begin{array}{llll}\text { Retrieved } & 1 & \text { February 2021, from }\end{array}$ https://oxfordbusinessgroup.com/news/how-will-covid-19-affect-gulfdiversification-efforts.

[12] Impact of COVID 19 on development in Oman. (2021). Retrieved 1 February 2021, from https://www.squ.edu.om/research/ResearchOutput/Latest-Research-Highlights/ArticleID/865/Impact-of-COVID19-on-development-in-Oman.

[13] Impact of COVID-19 on Construction Projects | Protiviti - Oman. (2021). Retrieved 1 February 2021, from https://www.protiviti.com/OM-en/insights/covid-19-impactconstruction-projects.

[14] Lennane, A. (2021). Air freight rates on the up again, driven by more demand for less capacity - The Loadstar. Retrieved 1 February 2021, from https://theloadstar.com/air-freight-rates-on-the-up-again-drivenby-more-demand-for-less-capacity/.

[15] Medium Term Fiscal Plan (2020-2024). (2021). Retrieved 1 February 2021 , https://mof.gov.om/Portals/1/documents/Tawazon/MTFP\%20$\% 20$ English.pdf.

[16] NCSI. (2017, January 19). Monthly Statistical Bulletin: January 2017. Retrieved February 18, 2021, from https://www.ncsi.gov.om/Elibrary/LibraryContentDoc/bar_MSBJan\% 2020172_224fef9c-a457-4ad4-bc6a-2779c3dd368c.pdf.

[17] NCSI. (2018, January 21). Monthly Statistical Bulletin: January 2018 Retrieved February 18, 2021, from https://www.ncsi.gov.om/Elibrary/LibraryContentDoc/bar_JAN2018_ ac3db479-ccca-40e9-a369-21cf36432287.pdf.

[18] NCSI. (2019, January 23). Monthly Statistical Bulletin: January 2019. Retrieved February 18, 2021, from https://www.ncsi.gov.om/Elibrary/LibraryContentDoc/bar_MSB\%20J anuary_9b52b4a8-2163-4060-9000-3f521023556e.pdf.

[19] NCSI. (2020, April 20). Monthly Statistical Bulletin: April 2020. Retrieved February 18, 2021, from https://www.ncsi.gov.om/Elibrary/LibraryContentDoc/bar_bar_April $\% 2020203$ 0440cf13-96a7-4018-9d2c-9fb9f5a42750.pdf.

[20] NCSI. (2020, January 19). Monthly Statistical Bulletin: January 2020 Retrieved February 18, 2021, from https://www.ncsi.gov.om/Elibrary/LibraryContentDoc/bar_jan_2e3db 784-53f8-46e8-8d6d-60842be9b2d6.pdf.

[21] NCSI. (2020, July 20). Monthly Statistical Bulletin: July 2020. Retrieved February 18, 2021, from https://www.ncsi.gov.om/Elibrary/LibraryContentDoc/bar_Jul.\%2020 20_74153bec-4a16-490c-beb9-685017fe1ae9.pdf.

[22] NCSI. (2020, October 21). Monthly Statistical Bulletin: October 2020. Retrieved February 18, 2021, from https://www.ncsi.gov.om/Elibrary/LibraryContentDoc/bar_Oct.\%202 020_dfab71dd-f929-4639-b225-5719542e1 a6a.pdf.

[23] NCSI. (2021, January 20). Monthly Statistical Bulletin: January 2021. Retrieved February 17, 2021, from https://ncsi.gov.om/Elibrary/LibraryContentDoc/bar_Jan 2021_1131babc-2cdb-4990-93c6-fb67e19cdc2d.pdf.

[24] Oman Construction Market | Growth, Trends, and Forecast (2019 2024). (2021). Retrieved 1 February 2021, from https://www.mordorintelligence.com/industry-reports/omanconstruction-market.

[25] Oman's Civil Transactions Law (2021). Oman.

[26] Oman's Construction. (2019). The Big Show, 1-4.

[27] Oman's Economic Update - April 2020. (2021). Retrieved 1 February 2021, https://www.worldbank.org/en/country/gcc/publication/omaneconomic-update-april-2020.

[28] Oman's Total Public Expenditure Falls 8.4 Percent till June 2020. (2021). Retrieved 1 February 2021, from https://omannews.gov.om/NewsDescription/ArtMID/392/ArticleID/2 
European Journal of Business and Management Research www.ejbmr.org

1415/Oman\%E2\%80\%99s-Total-Public-Expenditure-Falls-84Percent-till-June-2020.

[29] Owtram, F., \& Hayek, M. (2021). Oman in the COVID-19 Pandemic: People, Policy and Economic Impact. Retrieved 1 February 2021, from https://blogs.1se.ac.uk/mec/2020/07/23/oman-in-the-covid-19pandemic-people-policy-and-economic-impact/.

[30] Saleh, M., \& Alalouch, C. (2015). Towards Sustainable Construction in Oman: Challenges \& Opportunities. Procedia Engineering, 118, 177 184. doi: 10.1016/j.proeng.2015.08.416.

[31] Strauss, A., \& Corbin, J. (1998). Basics of qualitative research (2nd ed.). Newbury Park, CA: Sage.

[32] Thomas, D. R. (2006). A general inductive approach for analyzing qualitative evaluation data. American journal of evaluation, 27(2), 237 246.

[33] Thomas, E. (2021). GlobalData: Oman's construction industry to contract sharply in 2020. Retrieved 1 February 2021, from https://www.worldcement.com/africa-middle-

east/11122020/globaldata-omans-construction-industry-to-contractsharply-in-2020/.

[34] Weisbrod, G., \& Weisbrod, B. (1997). Measuring economic impacts of projects and programs. Economic Development Research Group, 10, $1-11$.

[35] What are the possible causes and consequences of higher oil prices on the overall economy?. (2021). Retrieved 1 February 2021, from http://www.frbsf.org/education/publications/doctorecon/2007/novemb er/oil-prices-impact-economy S. Chen, B. Mulgrew, and P. M. Grant, "A clustering technique for digital communications channel equalization using radial basis function networks," IEEE Trans. on Neural Networks, vol. 4, pp. 570-578, July 1993. 